\title{
Synthesis and Anticancer Activity Of One Novel Thiopyrano[4,3-d]Pyrimidine Derivative Bearing A Indole-hydrazone
}

\author{
Chengyu Sun ${ }^{\mathrm{a}}$, Chen Chen ${ }^{\mathrm{b}}$, Shan $\mathrm{Xu}^{\mathrm{c}}$, Qingqing $\mathrm{Hu}^{\mathrm{d}}$,Pengwu Zheng ${ }^{\star \mathrm{e}}$ and \\ Wufu Zhu*f
}
School of Pharmacy, Jiangxi Science \& Technology Normal University, Nanchang 330013, China
a sunchengyu0902@126.com, ${ }^{\mathrm{b}}$ chen5950677@163.com, ${ }^{*} \mathrm{z}$ zhengpw@126.com,
fzhuwufu-1122@163.com

Keywords: Thiopyrano[4,3-d]pyrimidine; Synthesis; MTOR Inhibitors; Indole-hydrazone; Anticancer.

\begin{abstract}
A novel thiopyrano[4,3- $d]$ pyrimidin derivative bearing a indole-hydrazone was synthesized and structure was confirmed by ${ }^{1} \mathrm{H}$ NMR and MS. Moreover, this compound was evaluated for its cytotoxicity against the H460 cell lines and inhibitory activity against mTOR kinase at a concentration of $10 \mathrm{uM}$. The result indicated that this compound exhibited moderate activity against cancer cell line as well as mTOR kinase. At $10 \mu \mathrm{M}$ level, the inhibition rate of compound 1 against $\mathrm{H} 460$ cell lines and mTOR kinase was $39.6 \%$ and $47.0 \%$.
\end{abstract}

\section{Introduction}

Every year, there were millions of people died of cancer in the world. Moreover, the latest data from International Agency for Research on Cancer (IARC), indicated that the cancer incidence, mortality, and prevalence were on the rise. And the agency based on the GLOBOCAN 2012 estimates predicted that in 2025 the number of new cancer cases per year will reach 19.3 million [1]. Therefore, looking for safe and effective cancer treatments remains desirable.

Previous studies have found that the PI3K-Akt-mTOR signalling pathway plays an important role in the development of tumors [2].Therefore, developing inhibitors of this pathway has become one of the research hotspots in molecular targeted therapy for the treatment of human cancer [3]. After years' effort of the researchers, many small molecule inhibitors of this pathway were reported such as GDC-0941[4-10]. Compound BMCL-200908069-1 is an mTOR inhibitor with $\mathrm{IC}_{50}$ value of 0.27 $\mu \mathrm{M}$ [5]. Structure-activity relationships (SARs) showed that aryl hydrazones and morpholine-triazine moieties were essential for the mTOR activity. Therefore, in this study, we introduced an indole-hydrazone to design and synthesis a novel thiopyrano[4,3- $d]$ pyrimidine derivative(1). And the target compound was evaluated for its cytotoxicity against H460 cell lines and inhibitory activity against mTOR kinase.

\section{Materials and methods}

All melting points were obtained on a Büchi Melting Point B-540 apparatus and were uncorrected. NMR spectra were performed using Bruker $400 \mathrm{MHz}$ spectrometerswith TMS 210 as an internal standard. Mass spectra (MS) were taken in ESI mode on Agilent 1100 LC-MS. All the materials were obtained from commercial suppliers and used without purification, unless otherwise specified. Yields were not optimized.TLC analysis was carried out on silica gel plates GF254 .

\section{Synthesis of compounds}

The structures and the synthetic route were shown in Scheme 1. 

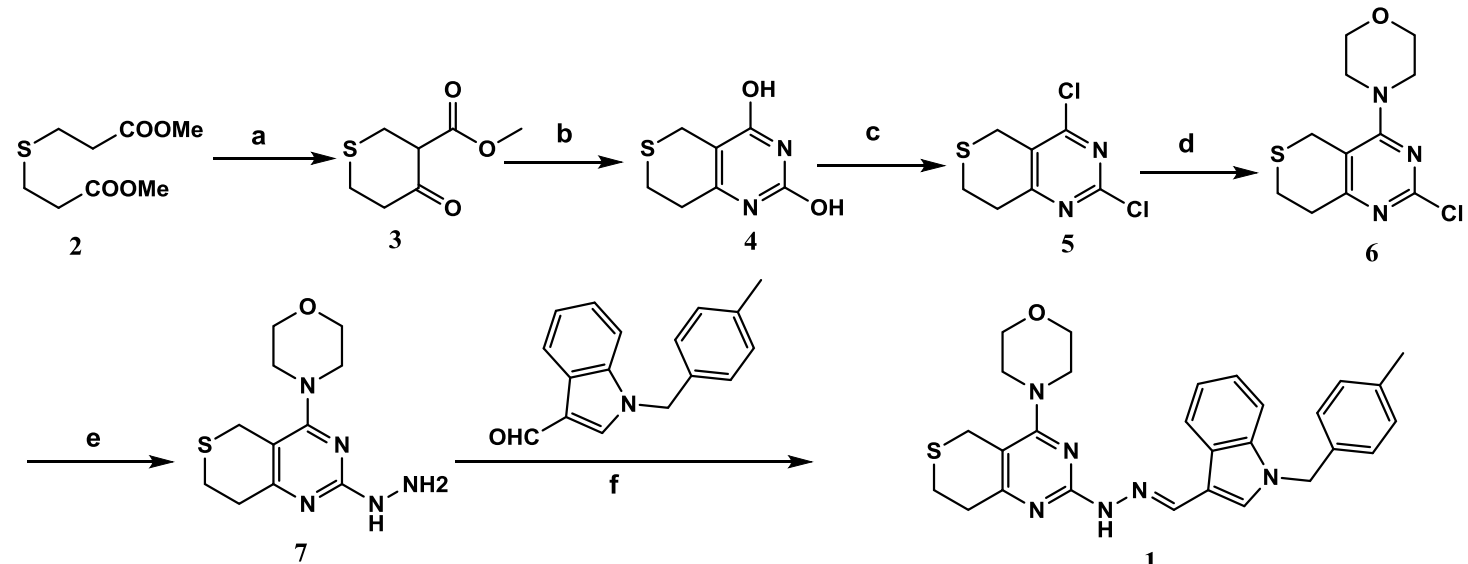

Scheme. 1 The synthetic route of compound 1

Reagents and conditions: (a) NaH, THF, rt, 3 h; (b) 3 equiv urea, $\mathrm{C}_{2} \mathrm{H}_{5} \mathrm{ONa}$, EtOH, reflux, $24 \mathrm{~h}$; (c) $\mathrm{POCl}_{3}$, reflux, $3 \mathrm{~h}$; (d) 2.4 equiv morpholine, $\mathrm{MeOH}$, rt, $1.5 \mathrm{~h}$; (e) $80 \% \mathrm{NH}_{2} \mathrm{NH}_{2} \cdot \mathrm{H}_{2} \mathrm{O}, 85^{\circ} \mathrm{C}, 1 \mathrm{~h}$; (f) EtOH, reflux, $2 \mathrm{~h}$.

Methyl 4-oxotetrahydro-2H-thiopyran-3-carboxylate (3). To the mixture of $\mathrm{NaH}(60 \%, 8.19 \mathrm{~g}$, $0.205 \mathrm{~mol})$ and anhydrous THF $(100 \mathrm{~mL})$, a solution of dimethyl 3,3'-thiodipropionate $(31.8 \mathrm{~g}, 0.154$ mol) in anhydrous THF ( $40 \mathrm{~mL})$ was added via a dropping funnel over $1 \mathrm{~h}$ at room temperature under $\mathrm{N}_{2}$. After stirring for $2 \mathrm{~h}$ at r.t, the reaction was complete by TLC analysis (20\%EtOAc in petroleum ether). The mixture was transferred to a beaker, dilute hydrochloric acid was added slowly with stirring maintaining the temperature below $20{ }^{\circ} \mathrm{C}$, the final $\mathrm{pH}$ was 6-7. Then extracted with $\mathrm{CH}_{2} \mathrm{Cl}_{2}$ $(3 \times 50 \mathrm{~mL})$. The combined organic layers were washed with brine $(3 \times 50 \mathrm{~mL})$, and dried over $\mathrm{Na}_{2} \mathrm{SO}_{4}$, the filtrate was concentrated under reduced pressure to afford $\mathbf{3}$ as a yellow viscous oil $(26.8 \mathrm{~g}, 99.8 \%)$ and was used for next step without further purification. ESI-MS m/z: $[\mathrm{M}+\mathrm{H}]^{+} 175.2$

7,8-dihydro-5H-thiopyrano[4,3- $d$ ]pyrimidine-2,4-diol (4). Finely cut sodium metal (16.2g, $0.704 \mathrm{~mol}$ ) was added into $300 \mathrm{~mL}$ anhydrous ethanol at ice bath with stirring. After the sodium metal was completely consumed, urea $(32.7 \mathrm{~g}, 0.545 \mathrm{~mol})$ and $\mathbf{3}(31.3 \mathrm{~g}, 0.180 \mathrm{~mol})$ was added to the solution. The mixture was refluxed for $24 \mathrm{~h}$. The reaction mixture was concentrated under reduced pressure and the residue was poured onto ice water, then adjusted the $\mathrm{pH}$ to 6-7 with acetic acid under ice bath , filtration, the filter cake was washed with ice-water, dried to obtain a white solid $(13.6 \mathrm{~g}, 41.2 \%)$. m.p. $>300^{\circ} \mathrm{C}$. ESI-MS m/z: [M-H] ${ }^{-} 183.2,{ }^{1} \mathrm{H}$ NMR (400 MHz, DMSO) $\delta 11.10(\mathrm{~s}, 1 \mathrm{H}), 10.75(\mathrm{~s}, 1 \mathrm{H})$, $3.39(\mathrm{~s}, 2 \mathrm{H}), 2.80(\mathrm{t}, J=5.8 \mathrm{~Hz}, 2 \mathrm{H}), 2.57(\mathrm{t}, J=5.6 \mathrm{~Hz}, 2 \mathrm{H})$.

2,4-dichloro-7,8-dihydro-5H-thiopyrano[4,3- $d$ ] pyrimidine (5). A mixture of 4 (3.03g, 0.016 mol), $\mathrm{POCl}_{3}(20 \mathrm{~mL})$ was refluxed for $3 \mathrm{~h}$. The reaction mixture was slowly added to ice/water with vigorous stirring yielding a precipitate. The mixture was then filtered to yield $\mathbf{5}$ as a yellow solid (3.12g, 85.7\%). m.p. 87.1-87.9 ${ }^{\circ} \mathrm{C} .{ }^{1} \mathrm{H}$ NMR $(400 \mathrm{MHz}, \mathrm{CDCl} 3) \delta 3.81(\mathrm{~s}, 2 \mathrm{H}), 3.23(\mathrm{t}, J=5.9 \mathrm{~Hz}, 2 \mathrm{H})$, $2.96(\mathrm{t}, J=6.0 \mathrm{~Hz}, 2 \mathrm{H})$.

4-(2-chloro-7,8-dihydro-5H-thiopyrano[4,3-d]pyrimidin-4-yl)morpholine (6). To the mixture of $5(7.40 \mathrm{~g}, 0.033 \mathrm{~mol})$ and $\mathrm{MeOH}(150 \mathrm{~mL})$, morpholine $(7 \mathrm{~mL}, 0.08 \mathrm{~mol})$ was added drop-wise at room temperature. The reaction mixture then was stirred at room temperature for $1.5 \mathrm{~h}$. The mixture was then filtered, washed with water and $\mathrm{MeOH}$, to yield the title compound as a white solid (6.84 g, 75.3\%). m.p. $161.1-162.4{ }^{\circ} \mathrm{C}$. ESI-MS $\mathrm{m} / z:[\mathrm{M}+\mathrm{H}]^{+}{ }^{2}$ 272.1. ${ }^{1} \mathrm{H}$ NMR $\left(400 \mathrm{MHz}, \mathrm{CDCl}_{3}\right) \delta 3.81(\mathrm{~s}, 2 \mathrm{H})$, $3.23(\mathrm{t}, \mathrm{J}=5.9 \mathrm{~Hz}, 2 \mathrm{H}), 2.96(\mathrm{t}, \mathrm{J}=6.0 \mathrm{~Hz}, 2 \mathrm{H})$.

4-(2-hydrazinyl-7, 8-dihydro-5H-thiopyrano[4,3- $d]$ pyrimidin-4-yl)morpholine(7). A solution of $80 \%$ hydrazine hydrate $\left(\mathrm{NH}_{2} \mathrm{NH}_{2} . \mathrm{H}_{2} \mathrm{O}, 110 \mathrm{~mL}\right)$ and compound $6(3.47 \mathrm{~g}, 0.013 \mathrm{~mol})$ was stirred at $85^{\circ} \mathrm{C}$ for $1 \mathrm{~h}$. The precipitate was collected by filtration and washed with water, and dried to give 7 as white solid (1.73 g, 50.7\%). m.p. $172.1-173.2^{\circ} \mathrm{C}$. ESI-MS m/z: $[\mathrm{M}+\mathrm{H}]^{+}$268.2. ${ }^{1} \mathrm{H}$ NMR $(400 \mathrm{MHz}$, DMSO) $\delta 7.66(\mathrm{~s}, 1 \mathrm{H}), 4.07(\mathrm{~s}, 2 \mathrm{H}), 3.73-3.66(\mathrm{~m}, 4 \mathrm{H}), 3.54(\mathrm{~s}, 2 \mathrm{H}), 3.18(\mathrm{~s}, 4 \mathrm{H}), 2.89(\mathrm{t}, J=6.1 \mathrm{~Hz}$, $2 \mathrm{H}), 2.82(\mathrm{t}, J=6.0 \mathrm{~Hz}, 2 \mathrm{H})$. 
(E)-4-(2-(2-((1-(4-methylbenzyl)-1H-indol-3-yl)methylene)hydrazinyl)-7,8-dihydro-5H-thiopy rano[4,3- $d$ ]pyrimidin-4-yl)morpholine(1). A mixture of compound 7 (53mg,0.20 mmol),1-(4-methylbenzyl)- $1 H$-indole-3-carbaldehyde $(0.20 \mathrm{mmol})$ and one drop of glacial acetic acid in absolute ethanol $(10 \mathrm{~mL})$ was refluxed for $2 \mathrm{~h}$. The mixture was cooled, separated by filtration and washed with EtOH to afford the target compound as pale yellow solid (77.6 mg, 78\%). m.p. 140.5-142. ${ }^{\circ} \mathrm{C}$. ESI-MS m/z: $[\mathrm{M}+\mathrm{H}]^{+}$499.2. ${ }^{1} \mathrm{H}$ NMR (400 MHz, DMSO) $\delta 10.60(\mathrm{~s}, 1 \mathrm{H}), 8.49(\mathrm{~d}, J=$ $7.5 \mathrm{~Hz}, 1 \mathrm{H}), 8.24(\mathrm{~s}, 1 \mathrm{H}), 7.77(\mathrm{~s}, 1 \mathrm{H}), 7.45(\mathrm{~d}, J=8.0 \mathrm{~Hz}, 1 \mathrm{H}), 7.17-6.99(\mathrm{~m}, 6 \mathrm{H}), 5.36(\mathrm{~s}, 2 \mathrm{H}), 3.76$ (s, 4H), 3.59 (s, 2H), $3.34(\mathrm{~s}, 4 \mathrm{H}), 2.91(\mathrm{~d}, J=5.9 \mathrm{~Hz}, 4 \mathrm{H}), 2.23(\mathrm{~s}, 3 \mathrm{H})$.

\section{Biological Evaluation}

Cytotoxicity assay in vitro . The cytotoxic activities of compound 1 were evaluated with human lung cancer (H460) cell lines by the standard MTT assay in vitro, with GDC-0941 as the positive controls. The cancer cell lines was cultured in minimum essential medium (MEM) supplement with $10 \%$ fetal bovine serum (FBS).Approximately $4 \times 10^{3}$ cells, suspended in MEM medium, were plated onto each well of a $96-w e l l$ plate and incubated in $5 \% \mathrm{CO} 2$ at $37^{\circ} \mathrm{C}$ for $24 \mathrm{~h}$. The test compound at indicated final concentrations were added to the culture medium and the cell cultures were continued for $72 \mathrm{~h}$. Fresh MTT was added to each well at a terminal concentration of $5 \mu \mathrm{g} / \mathrm{mL}$ and incubated with cells at $37^{\circ} \mathrm{C}$ for $4 \mathrm{~h}$. The formazan crystals were dissolved in $100 \mu \mathrm{L}$ DMSO each well, and the absorbency at 492 $\mathrm{nm}$ (for absorbance of MTT formazan) and $630 \mathrm{~nm}$ (for the reference wavelength) was measured with the ELISA reader.

mTOR Kinase Assay [10]. The mTOR kinase activity of the compound 1 was determined using LANCE® Ultra time-resolved fluorescence resonance energy transfer (TR-FRET) assay following the manufacturer's instructions, with compounds mTOR inhibitors BMCL-200908069-1 and PI103 as positive controls. Briefly, mTOR enzyme (10 nM), ATP (21.6 uM), ULight-4E-BP1 Peptide (100 nM) and test compounds were diluted in kinase buffer (50 mM HEPES pH 7.5,1 mM EGTA, $3 \mathrm{mM} \mathrm{MnCl} 2$, $10 \mathrm{mM} \mathrm{MgCl} 2,2 \mathrm{mM}$ DTT and 0.01\%Tween-20). The reactions were performed in white 384-well Optiplates (PerkinElmer, MA, USA) at room temperature for $1 \mathrm{~h}$ and stopped by adding EDTA to 16 mM. Eu-anti-phospho-4E-BP1 (Thr37/46) Antibody (PerkinElmer, MA, USA) was then added to each well to a final concentration of $2 \mathrm{nM}$. The intensity of the light emission was measured with an EnVision ${ }^{\circledR}$ Multilabel Reader (PerkinElmer, MA, USA) in TR-FRET mode (excitation at $320 \mathrm{~nm}$ and emission at $665 \mathrm{~nm})$.

\section{Results}

The in vitro anticancer activity of the target compound was studied on the H460 cell and mTOR kinase. The test result was listed in Table 1.

Table 1 The inhibition rate of $\mathrm{H} 460$ cell and mTOR kinase of $\mathbf{1}$ at $10 \mu \mathrm{M}$ levels

\begin{tabular}{ccc}
\hline \multirow{2}{*}{ Compound } & \multicolumn{3}{c}{ Inhibition rate at $10 \mu \mathrm{M}(\%)$} \\
\cline { 2 - 3 } & H460 & mTOR \\
\hline $\mathbf{1}$ & 39.6 & 47.0 \\
BMCL-200908069-1 & - & 76.1 \\
PI103 & - & 98.6 \\
GDC-0941 & 58.7 & - \\
\hline
\end{tabular}

From Table 1, we could see that at a concentration of $10 \mathrm{uM}$, the inhibition rate of compound 1 against $\mathrm{H} 460$ cell lines was $39.6 \%$, and the inhibition rate against mTOR kinase was $47.0 \%$. Although the inhibition rate is lower than positive controls GDC-0941, BMCL-200908069-1, and PI103, it still indicate that the introduction of indole-hydrazone is essential to this kind of compounds. This result suggested that thiopyrano[4,3- $d]$ pyrimidine derivative bearing a indole-hydrazone is worthy to study further. 


\section{Conclusions}

In a conclusion, a novel of thiopyrano[4,3- $d$ ]pyrimidine derivative bearing a indole-hydrazone moiety is designed, synthesized and evaluated for their activity against the cancer cell lines (H460) and mTOR kinase. The result indicated that the target compound exhibited moderate cytotoxicity and inhibitory activity against H460 cell lines and mTOR kinase, respectively. Further modification and SAR studies based on thiopyrano[4,3- $d]$ pyrimidine derivatives are ongoing in our group.

\section{Acknowledgments}

We gratefully acknowledge the generous support provided by The National Natural Science Funds of China (No. 80140357), Project supported by the Natural Science Foundation of Jiangxi Province of China (No. 20142BAB215020).

\section{References}

[1] Ferlay J, Soerjomataram I, Ervik M, et al. GLOBOCAN 2012 v1.0, Cancer Incidence and Mortality Worldwide: IARC CancerBase No. 11 [Internet]. Lyon, France: International Agency for Research on Cancer (2014).

[2] Wee S, Lengauer C, Wiederschain D. Class I A phosphoinositide 3-kinase isoforms and human tumorigenesis:implications for cancer discovery and development. J. Curr Opin Oncol, 20.1(2008) 77-82

[3] Vanhaesebroeck B, Stephens L, Hawkins P. PI3K signalling: the path to discovery and understanding. J. Nature Reviews Molecular Cell Biology, 13.3(2012) 195-203.

[4] Folkes A J, Ahmadi K, Alderton W K, et al. The identification of 2-(1 H-Indazol-4-yl)-6-(4methanesulfonyl-piperazin-1-ylmethyl)-4-morpholin-4-yl-thieno [3, 2- $d$ ] pyrimidine (GDC-0941) as a potent, selective, orally bioavailable inhibitor of class I PI3 kinase for the treatment of cancer. J. Journal of medicinal chemistry, 51.18(2008) 5522-5532.

[5] Menear K A, Gomez S, Malagu K, et al. Identification and optimisation of novel and selective small molecular weight kinase inhibitors of mTOR. J. Bioorganic \& medicinal chemistry letters, 19.20(2009) 5898-5901.

[6] Shao T, Wang J, Chen J G, et al. Discovery of 2-methoxy-3-phenylsulfonamino-5-(quinazolin-6-yl or quinolin-6-yl) benzamides as novel PI3K inhibitors and anticancer agents by bioisostere. J. European journal of medicinal chemistry, 75(2014) 96-105.

[7] González, Sonia Martínez, et al. Imidazo [1, 2-a] pyrazines as novel PI3K inhibitors. J.Bioorganic \& medicinal chemistry letters, 22.5 (2012) 1874-1878.

[8] Lee, Wendy, et al. A hit to lead discovery of novel N-methylated imidazolo-, pyrrolo-, and pyrazolo-pyrimidines as potent and selective mTOR inhibitors. J. Bioorganic \& medicinal chemistry letters, 23.18 (2013) 5097-5104.

[9] Estrada, Anthony A., et al. Pyrimidoaminotropanes as potent, selective, and efficacious small molecule kinase inhibitors of the mammalian target of rapamycin (mTOR). J. Journal of medicinal chemistry, 56.7 (2013) 3090-3101.

[10]Zhu W, Liu Y, Zhai X, et al. Design, synthesis and 3D-QSAR analysis of novel 2-hydrazinyl-4-morpholinothieno $[3,2-d]$ pyrimidine derivatives as potential antitumor agents. J. European journal of medicinal chemistry, 57(2012) 162-175. 